\title{
Development of Wear-Resistant Coatings for Cobalt-base Alloys
}

\author{
B.V. Cockeram
}

USDOE contract No. DE-AC11-98PN38206

\section{NOTICE}

This report was prepared as an account of work sponsored by the United States Government. Neither the United States, nor the United States Department of Energy, nor any of their employees, nor any of their contractors, subcontractors, or their employees, makes any warranty, express or implied, or assumes any legal liability or responsibility for the accuracy, completeness or usefulness of any information, apparatus, product or process disclosed, or represents that its use would not infringe privately owned rights. 


\section{DISCLAIMER}

This report was prepared as an account of work sponsored by an agency of the United States Government. Neither the United States Government nor any agency thereof, nor any of their employees, make any warranty, express or implied, or assumes any legal liability or responsibility for the accuracy, completeness, or usefulness of any information, apparatus, product, or process disciosed, or represents that its use would not infringe privately owned rights. Reference herein to any specific commercial product, process, or service by trade name, trademark, manufacturer, or otherwise does not necessarily constitute or imply its endorsement, recommendation, or favoring by the United States Government or any agency thereof. The views and opinions of authors expressed herein do not necessarily state or reflect those of the United States Government or any agency thereof. 


\section{DISCLAIMER}

Portions of this document may be illegible in electronic image products. Images are produced from the best available original document. 


\title{
Development of Wear-Resistant Coatings for Cobalt-base Alloys
}

\author{
B.V. Cockeram \\ Bettis Atomic Power Laboratory, P.O. Box 79, West Mifflin, PA 15122-0079.
}

The costs and hazards resulting from nuclear plant radiation exposure with activated cobalt wear debris could potentially be reduced by covering the cobalt-base materials with a wear resistant coating. However, the hardnesses of many cobalt-base wear alloys are significantly lower than conventional PVD hard coatings, and mechanical support of the hard coating is a concern. Four approaches have been taken to minimize the hardness differences between the substrate and PVD hard coating: (1) use a thin Cr-nitride hard coating with layers that are graded with respect to hardness, (2) use a thicker, multilayered coating ( $\mathrm{Cr}$-nitride or $\mathrm{Zr}$-nitride) with graded layers, (3) use nitriding to harden the alloy subsurface followed by application of a multilayered coating of $\mathrm{Cr}_{\text {-nitride, }}$ and (4) use of nitriding alone. Since little work has been done on application of PVD hard coatings to cobalt-base alloys, some details on process development and characterization of the coatings is presented. Scratch testing was used to evaluate the adhesion of the different coatings. A bench-top rolling contact test was used to evaluate the wear resistance of the coatings. The test results are discussed, and the more desirable coating approaches are identified. 


\section{Introduction}

Two approaches for reducing the costs and risks associated with nuclear plant contamination from activated cobalt wear debris are [1,2]: (1) replacement of the cobalt-base alloys with alternative cobalt-free wear materials, or (2) covering the cobalt-base alloys with a wear resistant coating to provide a cobalt-free wear surface. Covering the cobalt-base alloys with a wear resistant coating is a more practical and a lower risk approach to near-term cobalt reduction than the use of a cobalt-free material because coating failure would only result in the exposure of the proven base metals. Since most wear resistant Physical Vapor Deposited (PVD) coatings have a higher stiffness and hardness than cobalt-base alloys, support of the coating is a concern in high stress wear contact. Four approaches have been taken to minimize the differences in stiffness between the substrate and wear resistant coating: (1) use of a thin, multilayer chromium-nitride coating with alternating hard and less-stiff layers, (2) the use of a thick, multilayered coating with graded layers, (3) a duplex approach of using nitriding to harden the material subsurface followed by application of a multilayered chromium-nitride coating, and (4) application of nitriding or carburizing alone. The coatings were evaluated by 4-ball wear testing which simulates bearing wear, and scratch adhesion testing for a general screening of coating adhesion. Little data is available in the literature on the application of PVD hard coatings to cobalt-base alloys, and characterization of the coatings is discussed along with the test results.

\section{Materials and Procedures}

Flats for scratch adhesion testing $(3.175 \mathrm{~cm} \mathrm{X} 1.27 \mathrm{~cm} \mathrm{X} 0.64 \mathrm{~cm})$, drive ball $(1.27 \mathrm{~cm}$ diameter, Grade 10), and cup (Figure 1) for 4-ball wear testing were produced from various heats of Haynes 25 with the nominal compositions given in Table I. Stellite 3 balls $(1.27 \mathrm{~cm}$ diameter) and $17-4 \mathrm{PH}$ separators were also used in the 4ball wear test, see Table I. The 4-ball wear test involves six test pieces (Figure 1): (1) Haynes 25 drive ball, (2) three Stellite 3 intermediate balls, (3) a 17-4 PH separator, and (4) a Haynes 25 cup. The 4-ball wear testing was performed at Falex Corporation, Sugar Grove, IL in ambient $\left(20-30^{\circ} \mathrm{C}\right)$ deionized water. The intermediate balls sit in the separator in contact with the Haynes 25 cup. Application of $6.21 \mathrm{~kg}$ of load on the drive ball at the $30^{\circ}$

contact angle set by the separator produces a Hertzian contact stress of $2.42 \mathrm{GPa}$ at the ball surfaces [3]. The drive ball was rotated at 1200 RPM for 20 hours, which produces 300 RPM for the intermediate balls in the cup. Three different coatings were applied to the cup, drive ball, and intermediate balls for the 4-ball wear test (Table II): (1) thin, dual-layer chromium-nitride coating, (2) an ion nitrided base material, and (3) duplex coating. 
Flats were subjected to nano-scratch adhesion testing at MTS-Nano Instruments, Knoxville, TN using two indentor geometries [4,5]: (1) a $130 \mu \mathrm{m}$ diameter spherical sapphire indentor at loads from 0 to 500 milli-Newtons, and (2) a cube corner indentor (100 $\mu \mathrm{m}$ side) at loads up to 30 milli-Newtons. The coefficient of friction and penetration depth versus scratch distance were determined and the applied load was increased with scratch distance. The average hardness and average modulus versus depth were also measured using a sharp Berkovich diamond nano-indentor with at least seven indentations being made in the continuous stiffness mode [6].

\section{Coatings and Scratch Adhesion Testing}

Although previous experience on the plasma carburizing of cobalt-base alloys was not available, one run was made using pure methane with an applied power density of $1.75 \mathrm{Watts}_{\mathrm{in}}{ }^{2}$ to the Haynes 25 flats to produce a plasma glow discharge with a nominal substrate temperature of $593^{\circ} \mathrm{C}$ for the 48 hour run. Plasma carburizing resulted in a porous deposit (Table II) that was determined by microprobe and X-ray diffraction (XRD) to primarily consist of carbon and oxygen with the structure of amorphous carbon. Spalling of this carbon layer was observed in normal handling and a low nano-scratch adhesion value was measured (Table II). A hardness or modulus value could not be determined from the nano-indentation test due to the porous nature of the deposit. The poor adhesion and damage resistance indicates that plasma carburizing is not a suitable method to produce a wear resistant surface on Haynes 25.

A cathodic arc PVD process was used to produce a thick, dual-layer coating of zirconium-nitride ( $\mathrm{ZrN}$ ) by imposing a discrete change in nitrogen stoichiometry, see Table II. The $\mathrm{ZrN}$ coating was generally adherent, but a low density of macroparticle defects were observed on the surface [7]. The $9 \mu \mathrm{m}$ thick coating consisted of a thick $(\approx 7.5 \mu \mathrm{m})$ outer layer and a thinner $(\approx 1.5 \mu \mathrm{m})$ inner layer, but no difference in nitrogen content was detected using microprobe analysis. XRD analysis indicate that the coating was $\mathrm{ZrN}$ (ICDD card \# 02-0956) with slight peak shifts suggesting a slightly different stoichiometry ( $4.60 \AA$ for the coating versus $4.56 \AA$ for the ICDD card \# 02-0956). Although higher scratch adhesion values are generally expected for thick coatings [8], the critical load for the thicker $\mathrm{ZrN}$ coating was comparable to the thinner TiN coating (Table II). The hardness and modulus values for the $\mathrm{ZrN}$ and TiN coatings are significantly higher than Haynes 25 , which indicates that the $\mathrm{ZrN}$ coating layers have little grading in hardness. The large difference in hardness and modulus between Haynes 25 and the $\mathrm{ZrN}$ or TiN coating could result in coating failure under high-stress loading, and these coatings are poor candidates for Haynes 25. 
A reactive, unbalanced magnetron (UBM) sputtering process was used to produce multi-layer coatings with alternating layers of chromium-nitride $\left(\mathrm{Cr}_{2} \mathrm{~N}\right)$ and chromium-nitrogen solid solution ( $\mathrm{Cr}-\mathrm{N}(\mathrm{ss})$ ), see (Table II) [9]: (1) a thin dual layer coating ( $1 \mu \mathrm{m}$ thick) with a 2:1 ratio of $\mathrm{Cr}-\mathrm{N}(\mathrm{ss})$ to $\mathrm{Cr}_{2} \mathrm{~N}$ applied to Haynes 25 flats, balls, and cup, and Stellite 3 balls, and (2) a thick multilayer coating $(\approx 10 \mu \mathrm{m})$ with a $4 \mu \mathrm{m}$ inner layer of $\mathrm{Cr}-\mathrm{N}(\mathrm{ss}) / 1 \mu \mathrm{m}$ layer of $\mathrm{Cr}_{2} \mathrm{~N} / 4 \mu \mathrm{m}$ layer of $\mathrm{Cr}-\mathrm{N}(\mathrm{ss}) / 1 \mu \mathrm{m}$ outer layer of $\mathrm{Cr}_{2} \mathrm{~N}$ applied to Haynes 25 flats. Multiple cathode targets produce a dense plasma that ionizes a high density of the nitrogen and chromium for improved reactivity, adhesion, and coating quality. The coated parts were rotated $360^{\circ}$ on a substrate table in rotational fixturing (double rotation): (1) flats were coated on a rotating spindle, (2) balls were coated in a rotating wire basket fixture, and (3) cups were coated on an axial rotating spindle. Only a slight increase in surface roughness ( $R_{\mathrm{a}}=55 \AA$ to $82 \AA$ after coating) was observed for the thin dual layer coating, while a larger increase $\left(R_{2}=55 \AA\right.$ to $271 \AA$ ) was observed for the thick multilayer chromium-nitride coating from ion bombardment during the UBM coating process. The thick multilayer chromium-nitride coating in Figure 2a was smooth and adherent, with two alternating layers of $4 \mu \mathrm{m}$ of $\mathrm{Cr}-\mathrm{N}(\mathrm{ss})$ and $1 \mu \mathrm{m}$ of $\mathrm{Cr}_{2} \mathrm{~N}$. The thin dual layer chromium-nitride coating in Figure $2 \mathrm{~b}$ is about $1 \mu \mathrm{m}$ in thickness (Table II) with a thicker inner $\mathrm{Cr}-\mathrm{N}(\mathrm{ss})$ layer and outer $\mathrm{Cr}_{2} \mathrm{~N}$ layer thickness consistent with the 2:1 ratio. The coating thickness on the Haynes 25 and Stellite 3 balls was fairly uniform (variation of less than $0.1 \mu \mathrm{m}$ ), based on measurements from metallographic sections. XRD analysis showed that both the thick and thin coatings consisted of $\mathrm{Cr}_{2} \mathrm{~N}$ (ICCD Card \#35-0803) and $\mathrm{Cr}-\mathrm{N}(\mathrm{ss})$ as a chromium-nitrogen solid solution (Card \#1 1-0065).

A nano-scratch adhesion value for the thick mulitlayer $\mathrm{Cr}$-nitride coating could not be determined because coating damage was not produced at the maximum applied load, see Table II. The large coating thickness, roughness, and excellent coating adherence likely prevents coating damage from the nano-indentor. The peak hardness and modulus of the thick multilayer chromium-nitride coating measured using the nano-indentation method in Table II are a close match to the Haynes 25 base material. The use of a composite layered coating with a high fraction of a relatively compliant $\mathrm{Cr}-\mathrm{N}(\mathrm{ss})$ layers (Figure 2a) apparently produces damage tolerance, adherence, and a match in hardness and modulus to the base material, with promise for high stress loading applications. A high nano-scratch adhesion value was measured in Table II for the thin dual layer $\mathrm{Cr}$-nitride coating, and the coating damage produced in the nano-scratch adhesion test was very mild. Lower adhesion values and significantly greater coating damage was observed for the $\mathrm{ZrN}$ and TiN coatings in Table II than the thin dual layer chromium-nitride coating, which indicates that the thin dual layer $\mathrm{Cr}$-nitride coating was significantly more adherent and damage 
tolerant. The peak hardness and modulus for the thin dual layer chromium-nitride coating in Table II are slightly higher than the Haynes 25 substrate and the thick multilayer chromium-nitride coating. The smaller layer thickness and lower fraction of more compliant $\mathrm{Cr}-\mathrm{N}(\mathrm{ss})$ layer $\left(\mathrm{CrN}(\mathrm{ss}): \mathrm{Cr}_{2} \mathrm{~N}\right.$ ratio of 2:1) results in a slightly higher hardness and modulus for the thin dual layer coating, but the hardness and modulus values are a much closer match to the substrate than the $\mathrm{ZrN}$ and TiN coatings.

Ion nitriding is a commercial process used to raise the subsurface hardness and improve wear resistance by a surface interdiffusion of nitrogen. Ion nitriding has been successfully used to improve the wear resistance of other Co-base alloys (Stellite 6) [10], but no commercial experience was found on ion nitriding Haynes 25 or Stellite 3. Two different ion nitriding temperatures $\left(510^{\circ} \mathrm{C}\right.$ for $48 \mathrm{~h}$ and $566^{\circ} \mathrm{C}$ for $\left.48 \mathrm{~h}\right)$ and a $566^{\circ} \mathrm{F}$ for $96 \mathrm{~h}$ ion nitriding treatments were initially evaluated. The $556^{\circ} \mathrm{C} / 48 \mathrm{~h}$ ion nitriding run produced the smallest layer thickness variation and lower amount of surface roughening, and was chosen for the final ion nitriding conditions. Ion nitriding increased the surface roughness of the Haynes 25 balls ( $R_{a}=0.5 \mu$-inches to $R_{a}=11-20 \mu$-inches) and Haynes 25 cup $\left(R_{a}=1\right.$ to $5 \mu$-inches to $R_{a}=11-16 \mu$-inches). Since the surface finishing of metals involves the deformation or smearing of metal, ion nitriding typically increases the surface roughness as the thermal activation results in relaxation of the surface smearing [11]. Based on the limited kinetic data plotted in Figure 3a, the parabolic growth rates for the nitride layer are fairly similar for the $510^{\circ} \mathrm{C}\left(4.8 \times 10^{-12} \mathrm{~cm}^{2} / \mathrm{s}\right)$ and $556^{\circ} \mathrm{C}\left(5.3 \times 10^{-12} \mathrm{~cm}^{2} / \mathrm{s}\right)$ processing temperature. The low activation energy $(10.7 \mathrm{KJ} / \mathrm{mol}-\mathrm{K})$ determined from this limited kinetic data indicates that either a grain boundary diffusion, surface diffusion, or gas phase diffusion mechanism is dominant. Any of these mechanisms would be expected to produce a rougher surface than a process limited by bulk diffusion. Ion nitriding of Haynes 25 produces an adherent nitride compound zone with a diffusion zone that is about 1/4 the nitride layer thickness, see Figure $3 \mathrm{~b}$. Microprobe and XRD analysis shows that the nitride compound is similar in composition to the substrate with the CrN (ICDD card \# 11-0065) structure, i.e. this is a $(\mathrm{Co}, \mathrm{Cr}, \mathrm{W}, \mathrm{Ni}, \mathrm{Fe}) \mathrm{N}$ nitride compound. The Stellite 3 base material has a two-phase microstructure of dendrites and interdendrite $\mathrm{Cr}$-carbides. Microprobe and XRD analysis shows that the ion nitriding layer grown on the Stellite 3 ball has a two-phase structure consisting of interdendritic $\mathrm{Cr}$-carbide phases and dendrite regions converted into a nitride $((\mathrm{Co}, \mathrm{Cr}, \mathrm{W}, \mathrm{Ni}, \mathrm{Fe}) \mathrm{N})$ compound with the $\mathrm{CrN}(\mathrm{ICDD}$ card \# 11-0065) structure. A high iron content (possibly with higher carbon) was observed on the outer edge of the nitride layers from the steel parts used in fixturing. Since the thickness of the iron-rich area is estimated to be less than $1 \mu \mathrm{m}$, the influence of this surface layer on the general 
wear performance of the nitride layer is expected to be minimal. Since the ion nitride surfaces were fairly rough, accurate measurement of a nano-scratch adhesion value was difficult, and a critical load was not detected at the maximum applied load in Table II. Surface examinations of the scratches showed excellent adhesion, no cracking of the nitride layer, and a smeared or ductile appearance. Nano-indentation testing summarized in Table II shows that both the modulus and peak hardness of the nitrided layer were lower than the Haynes 25 base material. Since the total displacement of the nano-indentor is $1 \mu \mathrm{m}$, only the compliant, outer iron-rich layer on the nitrided compound is tested to give the relatively low modulus and hardness.

The duplex treatment is a combination of the two previous approaches: (1) ion nitriding surface modification to provide support, and (2) deposition of a graded chromium-nitride coating. Two different thicknesses of chromium-nitride coatings were applied to commercially ion nitrided substrates using a reactive, UBM process: (1) a thin $(1 \mu \mathrm{m})$ dual layer coating with a $\mathrm{Cr}-\mathrm{N}(\mathrm{ss}): \mathrm{Cr}_{2} \mathrm{~N}$ ratio of $2: 1$, and (2) a thicker $(6 \mu \mathrm{m})$ dual layer coating with a $\mathrm{Cr}-\mathrm{N}(\mathrm{ss}): \mathrm{Cr}_{2} \mathrm{~N}$ ratio of $4: 1$. The rough ion nitrided surfaces and outer iron-rich layer made deposition of the chromium-nitride coatings somewhat difficult. An alternative duplex coating was produced by low pressure ion nitriding in the sputter coating chamber at a significantly lower total pressure, nitrogen pressure (6:1 ratio of nitrogen to argon) and shorter time ( 1 hour) than used in commercial ion nitriding followed by immediate application of a thin $(0.7 \mu \mathrm{m})$ dual layer $\mathrm{Cr}_{2} \mathrm{~N} / \mathrm{Cr}-\mathrm{N}(\mathrm{ss})$ coating with a 3:2 ratio of $\mathrm{Cr}-\mathrm{N}(\mathrm{ss}): \mathrm{Cr}_{2} \mathrm{~N}$ (low-pressure duplex coating).

The increase in surface roughness from the ion nitrided surface to the duplex coated surface was negligible for the Haynes 25 balls $\left(R_{a}=11\right.$ to $21 \mu$-inches to $R_{a}=16 \mu$-inches) and cup $\left(R_{a}=11\right.$ to $16 \mu$-inches to $R_{2}=13$ to $18 \mu$-inches). The surfaces of the coupons given the low-pressure duplex treatment also experienced a slight increase in surface roughness $\left(R_{a}=56 \AA\right.$ to $\left.R_{a}=173 \AA\right)$. The thin duplex coating deposited on Haynes 25 in Figure 4 is approximately $1 \mu \mathrm{m}$ in thickness deposited with an outer $\mathrm{Cr}_{2} \mathrm{~N}$ layer $(-0.3 \mu \mathrm{m})$ and an inner $\mathrm{Cr}-\mathrm{N}(\mathrm{ss})$ layer $(\sim 0.7$ $\mu \mathrm{m}$ ) that is consistent with the $2: 1$ ratio, see Table II. The thickness of the chromium-nitride layer was also uniform on the Haynes 25 and Stellite 3 balls. The thick duplex coating appears to be tightly adherent to the ion nitride layer and approximately $6 \mu \mathrm{m}$ in thickness, see Table II. The low-pressure duplex treatment has produced a thin diffusion zone with an adherent and very thin outer chromium-nitride coating, see Table II. Microprobe and XRD analysis show that all of the duplex coatings consist of an outer layer of $\mathrm{Cr}_{2} \mathrm{~N}$ (ICDD card \#35-0803), inner layer of chromium metal or $\mathrm{Cr}-\mathrm{N}(\mathrm{ss})$, and the underlying nitride layer. Although iron was mixed in with the inner $\mathrm{Cr}-\mathrm{N}$ (ss) layers, the thin (Figure 4) and thick duplex coatings appear to be tightly adherent. 
As observed for the ion nitrided layer, the surface of the duplex coated coupons was rough, and a critical load was not detected at the maximum applied load, see Table II. No coating damage was produced from the nanoscratch test, and only ductile type smearing is observed, which indicates that both the thin and thick chromiumnitride duplex coatings are adherent and damage resistant. Nano-indentation hardness and modulus data obtained for the thick duplex coating had values significantly higher than the ion nitrided surface and lower than uncoated Haynes 25 , see Table II. Since the modulus and hardness values for the thick duplex coated substrate are slightly lower than Haynes 25 , and since this coating exhibits excellent adhesion, the duplex coatings should exhibit good wear resistance. The nano-scratch adhesion test value for the low-pressure nitrided, duplex coating was comparable to the thin dual layer chromium-nitride coating in Table II, and SEM examination of the scratch indicates that the coating damage was not severe. Nano-indentation measurements in Table II indicate that the modulus of the low-pressure duplex coated surface is comparable to Haynes 25 , while the coating hardness was more than a factor of two larger than Haynes 25. The lower adhesion value for the low-pressure nitrided, duplex coating indicates that the nitriding time was not long enough to develop a thick nitride layer for support of the chromium-nitride coating.

\section{Results of 4-ball Wear Testing}

The weight change data for the uncoated baseline tests in Table III were fairly low. The wear of the cups was determined by dual profilometry using a Taylor/Hobson Taly-surf profilometer, i.e. raceway profiles were taken from the same four areas (about $90^{\circ}$ apart) before and after test. The maximum wear depth for the cups in Table IV was 2.6 to $1.25 \mu \mathrm{m}$ with a slight increase in surface roughness. The wear depth was mainly localized in one region radially along the raceway of the cup. The Haynes 25 drive balls have a wear tract with a depth over $25.0 \mu \mathrm{m}$ from high stress, ball-to-ball contact with the Stellite 3 intermediate balls, see Table IV.

The weight changes for the thin chromium-nitride coated Haynes 25 cup, Stellite 3 intermediate balls, and separator in Table III were significantly lower than the respective changes in weight recorded for the uncoated samples. The weight loss of one chromium-nitride coated drive ball was much higher than the uncoated drive ball in Table III. The maximum wear depth of the raceways of the chromium-nitride coated cup (Table IV) was less than $1.25 \mu \mathrm{m}$, which is significantly lower than the wear depth measured for the uncoated cup. No change in surface roughness was observed for the chromium-nitride coated cups, which is further evidence that the coating was adherent and provided excellent protection. The wear depth of the Haynes 25 drive ball that exhibited the low weight-loss (Test \#3) was less than the uncoated drive ball, but a significantly larger wear depth of $\approx 51 \mu \mathrm{m}$ was 
observed for the coated ball with the large weight loss (Test \#4), see Table IV. Pre- and post-test profilometry of the chromium-nitride coated Stellite 3 intermediate ball in Table IV shows a decrease in surface roughness resulting from the smoothing of minor asperities on the as-coated surface during the wear test.

Metallography of the worn Haynes 25 cup, and Stellite 3 ball shows that the chromium-nitride coatings were intact after the 4-ball wear test. Damage is observed in the wear tract region of the Haynes 25 drive ball with the high weight loss (test \#4), where the high stress, ball-to-ball (point) contact loading produced failure of the chromium-nitride coating. Fractured debris from the chromium-nitride coating had been ground into the subsurface of the Haynes 25 drive ball, but the coating remained intact in regions around the wear tract with no change in thickness. Abrasive debris from coating failure produced higher wear only in the region of contact. Post-test coating thickness measurements in Table V for the chromium-nitride coated Stellite 3 ball were similar to the as-coated ball, and the coating was tightly adherent. The majority $(\approx 99 \%)$ of the chromium-nitride coating surface exhibited no microscopic regions of damage, but microscopic regions of coating spalling (less than $20 \mu \mathrm{m}$ in diameter) were observed in post-test SEM examination. This result indicates that the high stress-point contact from the Haynes 25 ball produced no significant damage to the harder Stellite 3 intermediate balls. Post-test metallographic and SEM examinations of the Haynes 25 cup show that the chromium-nitride coating was $\approx 99 \%$ intact after testing with only microscopic regions of coating damage observed (less than $20 \mu \mathrm{m}$ in diameter). These results show that the chromium-nitride coating was tightly adherent to the Stellite 3 intermediate balls and Haynes 25 cup, and produced a significant decrease in wear rate.

The weight changes observed for the ion nitrided Stellite 3 balls, Haynes 25 cup, and separator were comparable to or lower than the weight loss measured for the uncoated samples, see Table II. The weight changes observed for the ion nitrided Haynes 25 drive balls were more than a factor of two larger than the uncoated drive balls (Table III). The maximum wear of the ion nitrided cup in Table IV was only about $2.0 \mu \mathrm{m}$, which is less than the uncoated cup. Significant smoothing of the rough as-nitrided surface occurs during the wear test, which may produce the marginally higher weight changes for the ion nitrided cup than the uncoated cups in Table III. The wear of the ion nitrided Haynes 25 drive ball produced a larger maximum depth $(35.6 \mu \mathrm{m})$ and post-test surface roughness than the uncoated drive ball (Table IV). Pre- and post-test measurements of the ion nitrided Stellite 3 intermediate ball in Table III show a decrease in surface roughness from the smoothing of asperities during the wear test. 
Post-test metallography and SEM examinations of the worn Haynes 25 drive ball, cup, and Stellite 3 show that the ion nitride layer was generally intact after the 4-ball wear test. The ion nitride layer on the raceway of the Haynes 25 cup had a wide variation in thickness from a thick layer at the edge of the race to no ion nitride layer in the center of the race. The radius of the non-nitride region was about $0.22 \mathrm{~cm}$ or about $1 / 3$ of the $0.66 \mathrm{~cm}$ radius of the cup. No fracturing or failure of the nitride layer was observed on the worn cup. Since the ion nitrided surface compound has a composition similar to the base material, chemical differences cannot be used to detect failure of the ion nitrided compound. SEM, profilometry, and the low weight loss indicate that the ion nitride layer was adherent and has protected the Haynes 25 cup. Ion nitriding processing conditions (total pressure, nitrogen partial pressure, and plasma distribution) must be improved to produce a more uniform nitride layer thickness in the cup raceway. SEM examination of the Haynes 25 drive ball indicate that the ion nitride layer generally survived the high stress, point contact loading, but some regions of layer failure were observed. Failure of the nitride layer, which is harder and more abrasive in nature than the Haynes 25 base material, produced more aggressive wear of the drive ball. The ion nitride layer was fully intact in regions around the wear tract of the drive ball, and the post-test coating thickness measurements in Table $V$ were the same as the as-coated thickness, which indicates that nitride layer failure only produced higher wear in the region of contact. Although only a minor amount of nitride layer deadhesion was observed in the wear tract region of the ion nitrided Haynes 25 drive ball, these results indicate that point contact, high-stress loading must be avoided for the successful use of ion nitrided Haynes 25. Post-test coating thickness measurements in Table V from the ion nitrided Stellite 3 ball are only slightly lower than the pre-test measurements, and nitride layer damage was not observed.

The weight changes observed for the duplex coated Stellite 3 balls, Haynes 25 cup, and uncoated separator were comparable to or only a factor of two higher than the uncoated samples, see Table III. The weight changes observed for the duplex coated Haynes 25 drive balls were about a factor of five larger than the uncoated drive balls (Table III). The maximum wear in the raceways of the duplex coated cup $(1.27 \mu \mathrm{m})$ was less than the uncoated cup, see Table IV. The higher weight losses for the duplex coated cups are likely produced by the smoothing of surface asperities during test. A larger depth $(38.1 \mu \mathrm{m})$ and higher post-test surface roughness were observed for the duplex coated Haynes 25 drive ball than the uncoated drive ball (Table IV). Pre- and post-test measurements of the duplex coated Stellite 3 intermediate ball in Table IV show a significant decrease in surface roughness from the smoothing of asperities during the wear test. 
Post-test examinations of the duplex coated Haynes 25 drive ball, cup, and Stellite 3 ball show that the outer chromium-nitride layer was generally intact and adherent. The outer chromium-nitride layer was much thinner for the duplex coated cup than the chromium-nitride coated cup (Table V), which is likely attributed to a slightly higher amount of wear resulting from wear debris produced by the worn drive ball. SEM surface examinations of the worn duplex coated cup specimens shows no fracturing or failure of the top chromium-nitride layer. SEM examination of the wear tract region of the duplex coated Haynes 25 drive ball show that the outer chromium-nitride coating was fully removed with more damage to the nitride layer. The high stress, point contact loading in the wear tract region resulted in failure of the chromium-nitride coating, which produced hard debris that resulted in more significant wear of the duplex coating than observed for the ion nitrided drive ball. An adherent chromium-nitride layer was observed in regions outside the wear tract on the duplex coated drive ball, and the chromium-nitride coating thickness was the same as the as-deposited thickness (Table V). The deadhesion of the duplex coating observed in the wear tract region of the Haynes 25 drive ball shows that point contact, high-stress loading must be avoided for successful use of duplex coated Haynes 25. Post-and pre-test coating thickness measurements in Table V were similar for the duplex coated Stellite 3 ball, which indicates that only slight wear had occurred.

\section{Summary}

The results of nano-indentor scratch adhesion testing were used to identify potential wear coatings for cobalt-base alloy (Haynes 25) substrates: (1) thick and thin chromium-nitride coatings with layers of hard $\mathrm{Cr}_{2} \mathrm{~N}$ and softer $\mathrm{Cr}-\mathrm{N}(\mathrm{ss}),(2)$ ion nitriding to produce a nitride compound with a diffusion zone, and (3) thick and thin duplex coatings with a multilayered chromium-nitride coating (hard $\mathrm{Cr}_{2} \mathrm{~N}$ and softer $\mathrm{Cr}-\mathrm{N}(\mathrm{ss})$ layers) applied a nitride layer from previous ion nitriding. Based on the results of nano-indentation testing, these coatings are a close match in hardness and modulus to the Haynes 25 substrate.

Based on weight change, profilometry measurements, and examinations after 4-ball wear testing, the thin chromium-nitride coated coupons exhibited a significantly lower wear rate than the uncoated Haynes 25 coupons. The chromium-nitride coatings were adherent on the Stellite 3 intermediate balls and Haynes 25 cups, but coating de-adhesion was observed on the Haynes 25 drive ball from high stress, point contact loading. The chromiumnitride coating was the best coating candidate evaluated and could be used to reduce the wear rate and significantly reduce the release of cobalt wear debris. The wear of the ion nitride coupons was slightly higher than the chromiumnitride coated coupons, but comparable to the uncoated coupons. The wear of the duplex coated coupons was 
slightly higher than the uncoated coupons. Ion nitriding and duplex coatings provided less wear protection for

Haynes 25 than the chromium-nitride coating. The wear resistance of the ion nitriding and duplex coatings could be improved by the use of improved ion nitriding conditions and lapping the surfaces after ion nitriding.

\section{Acknowledgments}

This work was performed under USDOE Contracts. DE-AC11-93PN38195 and DE-AC11-98PN38206.

The technical comments and contributions of J. L. Hollenbeck, W.L. Wilson, and R.R. Koch are appreciated.

\section{References}

[1] B.V. Cockeram, R.F. Buck, and W.L. Wilson, Surface and Coatings Technology, 94/95 (1997) 495.

[2] S.A. Shiels, W.L. Wilson, K.W. Rosengarth, and G.L. Wire, Proceedings of the Third International Symposium on the Contribution of Materials Investigation to the Reduction of Problems Encountered in Pressurized Water Reactors, (Fontevraud, France, September 12-16, 1994). Available as WAPD-T-3032, DOE/OSTI (Oak Ridge TN, 1994).

[3] The Rolltact Test Machine, Industrial Tectonics Report No.106, 1988.

[4] H. Deng, T.W. Scharf, and J.A. Barnard, J. Appl. Phys., 81(8) (1997) 1.

[5] T.Y. Tsui, G.M. Pharr, W.C. Oliver, Y.W. Chung, E.C. Cutiongco, C.S. Bhatia, R.L. White, R.L. Rhoades, and S.M. Gorbatkin, MRS Res. Soc. Symp. Proc., 356 (1995) 767.

[6] W.C. Oliver and G.M. Pharr, J. Mater. Res., 7(6) (1992) 1564.

[7] W.D. Sproul, Cutting Tool Engineering, 46(1) (1994) 1.

[8] A.J. Perry, J. Valli, and P.A. Steinmann, Surf. and Coatings Technol., 36 (1988) 559.

[9] P. Ballhause, B. Hensel, and H. Schuessler, Mat. Sci. and Eng., A163 (1993) 193.

[10] P.H. Nowill, Proceedings of 2nd International Conference on Ion Nitriding/Ion Carburizing, ASMI (1990) 175.

[11] Surface Engineering, Materials Handbook, Volume 5, ASM-I, (1994). 
Table I. Nominal compositions of base materials used in 4-ball and scratch adhesion testing [Compositions in Weight\%]

\begin{tabular}{|c|c|c|c|c|c|c|c|c|c|c|}
\hline $\begin{array}{c}\text { Alloy / } \\
\text { Substrate }\end{array}$ & $\mathrm{Co}$ & $\mathrm{Cr}$ & $\mathrm{W}$ & $\mathrm{Ni}$ & $\mathrm{Mn}$ & $\mathrm{C}$ & $\mathrm{Fe}$ & $\mathrm{Si}$ & Other & $\begin{array}{c}\text { Hardness } \\
\text { HRC }\end{array}$ \\
\hline $\begin{array}{c}\text { Haynes 25 } \\
\text { Flats }\end{array}$ & $\mathrm{Bal}$ & 20.7 & 14.6 & 10.1 & 1.42 & 0.12 & 2.7 & 0.22 & $\begin{array}{c}0.008 \mathrm{P} \\
<.002 \mathrm{~S}\end{array}$ & 47 \\
\hline $\begin{array}{c}\text { Haynes 25 } \\
\text { Cups }\end{array}$ & $\mathrm{Bal}$ & 20.4 & 14.6 & 10.1 & 1.43 & 0.00 & 2.17 & 0.16 & $\begin{array}{l}0.013 \mathrm{P} \\
<.002 \mathrm{~S}\end{array}$ & 52 \\
\hline $\begin{array}{c}\text { Haynes 25 } \\
\text { Balls }\end{array}$ & $\mathrm{Bal}$ & 20.1 & 15.2 & 10.1 & 1.43 & 0.10 & 0.9 & 0.1 & $\begin{array}{c}0.01 \mathrm{P} \\
.0002 \mathrm{~S}\end{array}$ & 46 \\
\hline \begin{tabular}{c} 
Stellite 3 Balls \\
\hline
\end{tabular} & $\mathrm{Bal}$ & 30.04 & 11.82 & 1.82 & 0.35 & 2.20 & 1.66 & 0.81 & $\begin{array}{l}0.012 \mathrm{P} \\
0.012 \mathrm{~S} \\
.21 \mathrm{Mo} \\
.05 \mathrm{Ti}\end{array}$ & 53 \\
\hline $\begin{array}{c}17-4 \text { PH } \\
\text { Separator }\end{array}$ & -- & 16.5 & -- & 3.4 & 0.5 & 0.04 & $\mathrm{Bal}$ & 0.5 & $\begin{array}{l}3.4 \mathrm{Cu} \\
0.3 \mathrm{Nb} \\
0.01 \mathrm{P} \\
0.01 \mathrm{~S}\end{array}$ & 36 \\
\hline
\end{tabular}


TABLE II. Scratch adhesion critical load values, hardiness, and modulus values determined using a nano-indentor from testing performed at MTS-Nano Instruments.

All of the coatings/surface modifications were applied to Haynes 25 flats.

\begin{tabular}{|c|c|c|c|}
\hline $\begin{array}{l}\text { Coating } \\
\text { Surface Modification, Vendor }\end{array}$ & $\begin{array}{l}\text { Average Thickness } \\
\pm \text { Standard Deviation }\end{array}$ & $\begin{array}{l}\text { Critical Load } \\
\text { Valüe [miN] }\end{array}$ & $\begin{array}{l}\text { Hardnès /Modulus } \\
\text { [GPa/GPa] }\end{array}$ \\
\hline Uncoated Haynes 25 & N/A & N/A & $7.4 / 258.5$ \\
\hline \multicolumn{4}{|c|}{ Candidates Only subjected to scratch adhesion testing } \\
\hline $\begin{array}{l}\text { Thick multilayer chromium-nitride } \\
\text { Coating, } \mathrm{ACT}\end{array}$ & $10.4 \pm 1.1$ & NF & $14.2 / 270.4$ \\
\hline TiN Coating, GM & $2-3$ & 15 & $25.7 / 400.5$ \\
\hline ZrN Coating, PST & $8.9 \pm 0.9$ & $15-17$ & $26.0 / 405.9$ \\
\hline Plasma Carburizing, SC & $13.8 \pm 4.2$ & $8-10$ & N/A \\
\hline $\begin{array}{l}\text { Low-pressure Duplex Coating, } \\
\text { ACT }\end{array}$ & $\begin{array}{c}0.6 \pm 0.2 \\
\text { Diff. Zone }=1.1 \pm 0.3\end{array}$ & 23 & $14.2 / 258.5$ \\
\hline $\begin{array}{l}\text { Thick Duplex Coating, } \\
\text { AHT + ACT }\end{array}$ & $\begin{array}{c}\text { CrN Layer }=5.8 \pm 0.6 \\
\text { Nitride Layer }=11.7 \pm 1.3\end{array}$ & NF & $5.8 / 183.1$ \\
\hline \multicolumn{4}{|c|}{ Candidates Tested in 4-ball wear testing } \\
\hline $\begin{array}{c}\text { Thin dual layer } \\
\text { chromium-nitride Coating, ACT }\end{array}$ & $0.9 \pm 0.2$ & 22.0 & $19.3 / 290.5$ \\
\hline Ion Nitriding, AHT & $11.7 \pm 1.3$ & NF & $1.4 / 66.7$ \\
\hline $\begin{array}{c}\text { Thin Duplex Coating, } \\
\text { AHT }+ \text { ACT }\end{array}$ & $\begin{array}{c}\text { CrN Layer }=3.0 \pm 1.2 \\
\text { Nitride Laver }=117+13\end{array}$ & NF & Not Measured \\
\hline
\end{tabular}

Notes: 1. ACT $=$ Advanced Coating Technology Group, Materials Technology Laboratory, Northwestern University, Evanston, $\mathrm{IL}$.

2. $\quad$ AHT Corp. $=$ Advanced Heat Treat Corporation, Waterloo, IA.

3. $\quad$ PST $=$ Praxair Surface Technologies, Inc., Indianapolis, IN.

4. $\quad \dot{S} \mathrm{C}=$ Surface Combustion Corporation, Maume, $\mathrm{OH}$.

5. $\mathrm{GM}=$ General Magnaplate, Linden, NJ.

6. $\quad \mathrm{NF}=$ No Coating Failure Observed.

7. $\quad \mathrm{N} / \mathrm{A}=$ Could Not Be Determined. 
Table III. Measured weight loss of the 4-ball wear test components. All test were performed in room temperature DI water.

\begin{tabular}{|c|c|c|c|c|c|c|c|}
\hline \multirow{2}{*}{ Test Number } & \multirow{2}{*}{$\begin{array}{l}\text { Coating Deposited on } \\
\text { Haynes } 25 \text { drive ball, } \\
\text { Stellite } 3 \text { intermediate balls, } \\
\text { and Haynes } 25 \text { cup }\end{array}$} & \multirow{2}{*}{$\begin{array}{c}\text { Coating of } \\
7-4 \text { PH } \\
\text { separator }\end{array}$} & \multicolumn{4}{|c|}{ (1) Weight]loss [mg] } & \multirow{2}{*}{$\begin{array}{l}\text { Total Weight } \\
\text { Loss [mg] }\end{array}$} \\
\hline & & & Drive Ball & $\begin{array}{l}\text { Inter. Balls } \\
\text { (Total) }\end{array}$ & Separator & Cup & \\
\hline 1 & None & None & 4.8 & 6.0 & 10.2 & 3.4 & 21.8 \\
\hline 2 & None & None & 2.7 & 1.6 & 10.2 & 3.1 & 17.6 \\
\hline Average & & & 3.8 & 3.8 & 10.2 & 3.3 & 19.7 \\
\hline 3 & Dual CrN/Cr(ss) Coating & None & 1.9 & 1.5 & 4.6 & 0.1 & 8.1 \\
\hline 4 & Dual CrN/Cr(ss) Coating & None & 14.8 & 1.2 & 2.0 & 0.4 & 18.4 \\
\hline Average & & & 8.4 & 1.4 & 3.3 & 0.3 & 13.3 \\
\hline 5 & Ion Nitriding & None & 12.1 & 5.6 & 2.1 & 5.0 & 24.8 \\
\hline 6 & Ion Nitriding & None & 13.4 & 4.3 & 1.5 & 3.4 & 22.6 \\
\hline Average & & & 12.8 & 5.0 & 1.8 & 4.2 & 23.7 \\
\hline 7 & Duplex Coating & None & 24.8 & 6.9 & 0.5 & 5.8 & 38.0 \\
\hline 8 & Duplex Coating & None & 27.4 & 6.6 & 1.3 & 7.2 & 42.5 \\
\hline Average & & & 26.1 & 6.8 & 0.9 & 6.5 & 40.3 \\
\hline
\end{tabular}


Table $\mathrm{N}$. Summary of profilometry data for 4-ball wear test with range of $R_{2}$ values before and after test, maximum wear depth determined from dual profilometry for the cups, and maximum wear depth for the drive ball from a post-test trace.

\begin{tabular}{|c|c|c|c|c|}
\hline \multirow{2}{*}{$\begin{array}{c}\text { Wear Specimen } \\
\text { Type }\end{array}$} & \multirow{2}{*}{\begin{tabular}{l} 
Measurement \\
\hdashline$\quad \#$
\end{tabular}} & \multicolumn{2}{|c|}{ Range of $\hat{R}_{\alpha}[\mu$-inches $]$} & \multirow{2}{*}{$\begin{array}{l}\text { Maximum Wear Depth } \\
\therefore \quad \\
\end{array}$} \\
\hline & & Pre-test & Post Test & \\
\hline \multicolumn{5}{|l|}{ Uncoated Base-line Tests } \\
\hline Cup - Test \#1 & $1-4$ & $1-5$ & $6.3-16.8$ & 0.86 to 2.59 \\
\hline Drive Ball - Test \#1 & 1 & 0.5 & 34.4 & 26.1 \\
\hline Cup - Test \#2 & $1-4$ & $1-5$ & $4.8-5.3$ & $0.64-1.24$ \\
\hline Drive Ball - Test \#2 & 1 & 0.5 & 39.7 & 29.9 \\
\hline \multicolumn{5}{|c|}{ Dual CrN/Cr(ss) Coating Tests } \\
\hline Cup - Test \#3 & $1-4$ & $5.3-5.9$ & $5.7-6.0$ & $0.48-1.24$ \\
\hline Drive Ball - Test \#3 & 1 & 5.3 & 32.9 & 13.5 \\
\hline Cup - Test \#4 & $1-4$ & $6.3-7.8$ & $6.2-7.7$ & $0.41-1.14$ \\
\hline Drive Ball - Test \#4 & 1 & 5.3 & 192.9 & 51.7 \\
\hline Intermed. Ball - Test \#4 & 1 & 3.5 & 0.9 & $\mathrm{~N} / \mathrm{A}$ \\
\hline \multicolumn{5}{|c|}{ Ion Nitriding Surface Modification Tests } \\
\hline Cup - Test \#5 & $1-4$ & $11.9-16.7$ & $3.4-6.4$ & $1.19-1.45$ \\
\hline Drive Ball - Test \#5 & 1 & 11.1 & 132.9 & 36.0 \\
\hline Intermed. Ball - Test \#5 & 1 & 14.4 & 3.3 & N/A \\
\hline Cup - Test \#6 & $1-4$ & $12.0-34.3$ & $6.0-8.5$ & $1.85-2.08$ \\
\hline Drive Ball - Test \#6 & 1 & 12.8 & 132.0 & 24.8 \\
\hline \multicolumn{5}{|c|}{ Duplex Treatment: Standard Ion Nitriding + Cr(ss)/CrN Hard-coating Tests } \\
\hline Cup - Test \#7 & $1-4$ & $14.2-14.5$ & $5.0-6.3$ & $0.71-1.35$ \\
\hline Drive Ball - Test \#7 & 1 & 16.3 & 168.8 & 35.3 \\
\hline Intermed. Ball - Test \#7 & 1 & 13.4 & 4.2 & N/A \\
\hline Cup - Test \#8 & 1 & $13.3-18.2$ & $4.9-6.6$ & $0.08-0.23$ \\
\hline Drive Ball - Test \#8 & 1 & 16.3 & 178.8 & 36.9 \\
\hline
\end{tabular}


Table V. Post-test coating thickness measurements made using image analysis after 4-ball wear testing.

\begin{tabular}{|c|c|c|c|c|}
\hline $\begin{array}{l}\text { Coating } \\
\text { Surface } \\
\text { Módification }\end{array}$ & $\begin{array}{l}\text { Substrate } \\
\text { Material } \\
\text { Specimen }\end{array}$ & $\begin{array}{l}\text { Average Thickness } \\
+ \text { StandardDeviation } \\
\end{array}$ & $\begin{array}{l}\text { Maximum } \\
\text { Thickness } \\
{[\mathrm{cm}]}\end{array}$ & $\begin{array}{l}\text { Minimum Thickness } \\
{[\mu \mathrm{m}]}\end{array}$ \\
\hline \multirow[t]{5}{*}{$\begin{array}{l}\text { Thin } \mathrm{CrN} / \mathrm{Cr}(\mathrm{ss}) \\
\text { Coating }\end{array}$} & $\begin{array}{l}\text { Haynes } 25 \\
\text { Cup (Pst) }\end{array}$ & $0.9 \pm 0.2$ & 1.4 & 0.5 \\
\hline & $\begin{array}{c}\text { Haynes } 25 \\
\text { Ball (Pre) }\end{array}$ & $1.0 \pm 0.1$ & 1.5 & 0.6 \\
\hline & $\begin{array}{l}\text { Haynes } 25 \\
\text { Ball (Pst) }\end{array}$ & $0.8 \pm 0.4$ & 2.0 & 0.2 \\
\hline & $\begin{array}{c}\text { Stellite } 3 \\
\text { Ball (Pre) }\end{array}$ & $1.1 \pm 0.2$ & 2.2 & 0.6 \\
\hline & $\begin{array}{l}\text { Stellite } 3 \\
\text { Ball (Pst) }\end{array}$ & $1.2 \pm 0.2$ & 1.9 & 0.2 \\
\hline \multirow{5}{*}{$\begin{array}{l}\text { Ion Nitriding } \\
\text { Surface } \\
\text { Modification }\end{array}$} & $\begin{array}{l}\text { Haynes } 25 \\
\text { Cup (Pst) }\end{array}$ & Note 3 & 11.8 & 0.0 \\
\hline & $\begin{array}{l}\text { Haynes } 25 \\
\text { Ball (Pre) } \\
\end{array}$ & $11.0 \pm 1.2$ & 13.4 & 8.3 \\
\hline & $\begin{array}{l}\text { Haynes } 25 \\
\text { Ball (Pst) } \\
\end{array}$ & - $10.9 \pm 1.7$ & 14.0 & 7.4 \\
\hline & $\begin{array}{l}\text { Stellite } 3 \\
\text { Ball (Pre) } \\
\end{array}$ & $9.4 \pm 2.7$ & 15.2 & 0.6 \\
\hline & $\begin{array}{l}\text { Stellite } 3 \\
\text { Ball (Pst) } \\
\end{array}$ & $8.5 \pm 1.7$ & 11.3 & 4.9 \\
\hline \multirow{5}{*}{$\begin{array}{l}\text { Duplex } \\
\text { Treatment: } \\
\text { Standard } \\
\text { Ion Nitriding + } \\
\text { Cr(ss)/CrN } \\
\text { Coating }\end{array}$} & $\begin{array}{l}\text { Haynes } 25 \\
\text { Cup (Pst) }\end{array}$ & $\mathrm{CrN}$ Layer $=0.6 \pm 0.4$ & $2: 5$ & 0.2 \\
\hline & $\begin{array}{l}\text { Haynes } 25 \\
\text { Ball (Pre) } \\
\end{array}$ & $\begin{array}{c}\text { CrN Layer }=1.0 \pm 0.2 \\
\text { Nitride Layer }=11.0 \pm 1.2 \\
\end{array}$ & $\begin{array}{c}2.6 \\
13.4 \\
\end{array}$ & $\begin{array}{l}0.6 \\
8.3 \\
\end{array}$ \\
\hline & $\begin{array}{c}\text { Haynes } 25 \\
\text { Ball (Pst) }\end{array}$ & $\mathrm{CrN}$ Layer $=1.3 \pm 0.5$ & 3.3 & 0.2 \\
\hline & $\begin{array}{l}\text { Stellite } 3 \\
\text { Ball (Pre) } \\
\end{array}$ & $\begin{array}{c}\text { CrN Layer }=1.0 \pm 0.1 \\
\text { Nitride Layer }=9.4 \pm 2.7\end{array}$ & $\begin{array}{c}2.7 \\
15.2 \\
\end{array}$ & $\begin{array}{l}0.6 \\
0.6 \\
\end{array}$ \\
\hline & $\begin{array}{l}\text { Stellite } 3 \\
\text { Ball (Pst) }\end{array}$ & $\mathrm{CrN}$ Layer $=1.4 \pm 0.3$ & 2.5 & 0.6 \\
\hline
\end{tabular}

Notes: $1 . \quad$ Pre $=$ Pre-test measurement, see Table I.

2. $\quad$ Pst $=$ Post-test measurement after 4-ball wear testing.

3. Since the nitride layer thickness was zero in the center of the raceway, only the range of nitride layer thicknesses are reported. 


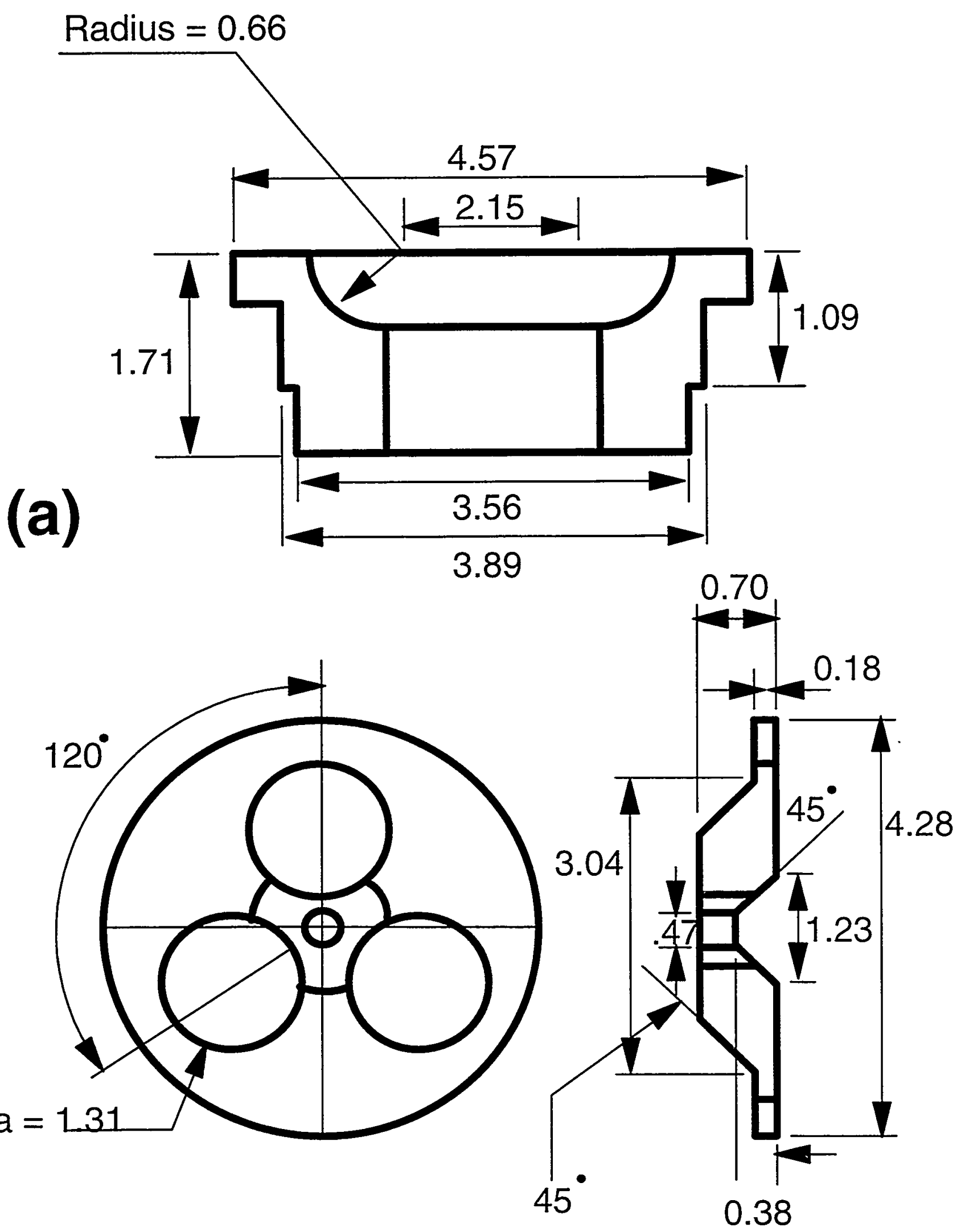

Fig. 1. 4-Ball wear test components: (a) Haynes 25 cup specimen, and (b) 17-4 PH (H1100) separator. The Haynes 25 drive ball and three Stellite 3 intermediate balls are $1.27 \mathrm{~cm}$ diameter. The Stellite 3 intermediate balls are placed inside the 17-4 PH separator and ride against the raceway of the Haynes 25 cup. The Haynes 25 drive ball contacts all three Stellite 3 intermediate balls through the center of the 17-4 PH separator. 


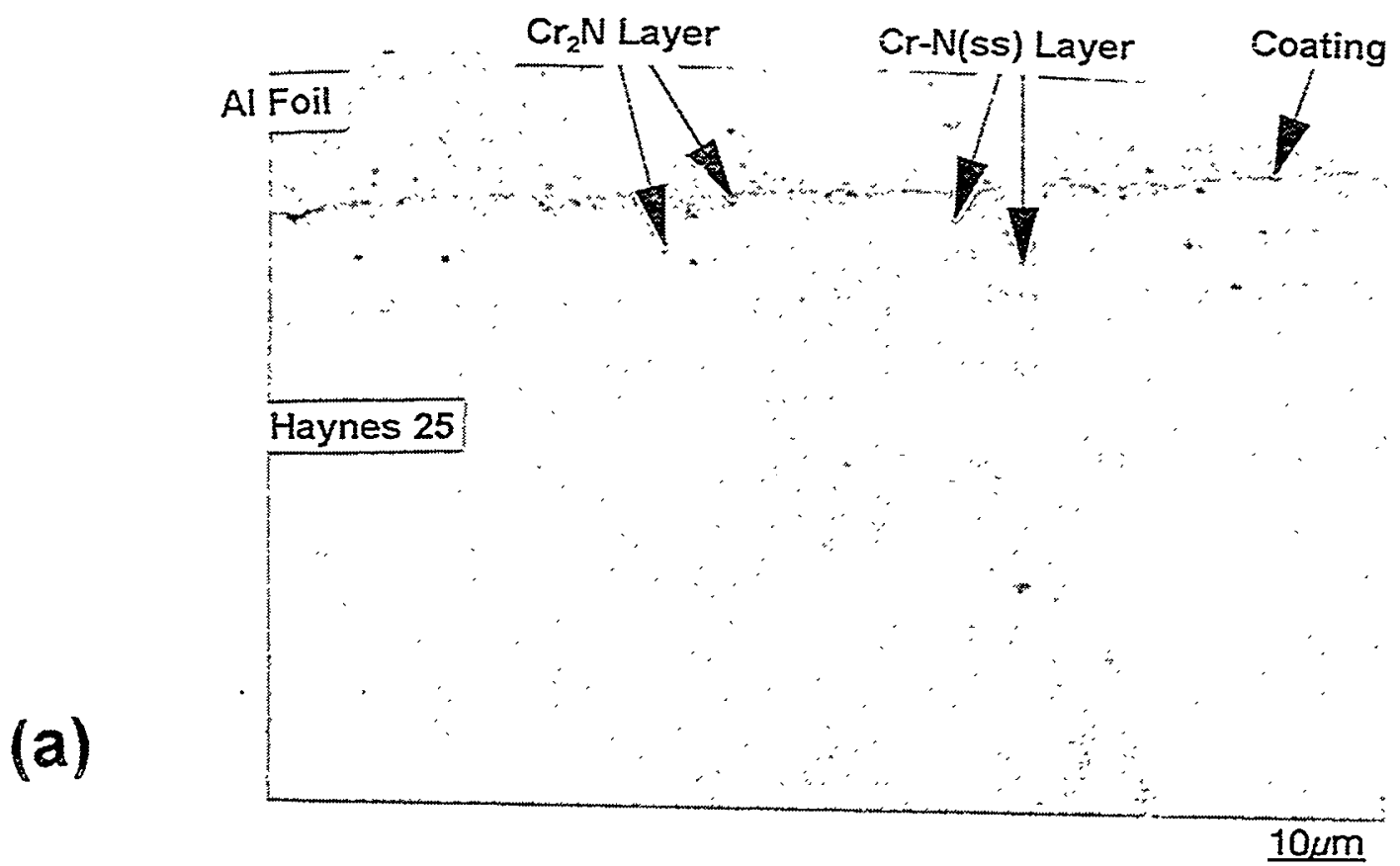

Haynes 25

A

\section{Coating

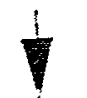

(b)

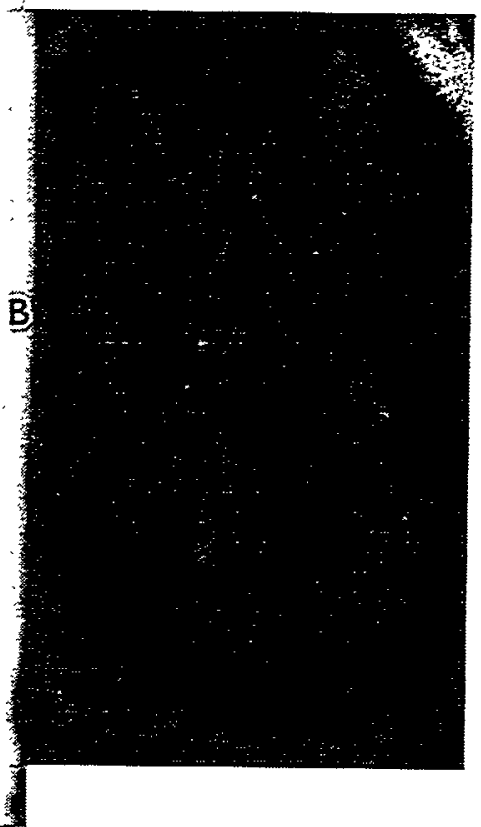

Fig. 2. Cross-section of chromium-nitride coatings deposited on Haynes 25 by Advanced Coating Technology: Group (ACT), Northwestern University: (a) optical micrograph of thick chromium-nitride coating in as-polished section showing an $1 \mu \mathrm{m}$ outer $\mathrm{Cr}_{2} \mathrm{~N}$ layer followed by $\mathrm{Cr}-\mathrm{N}(\mathrm{ss})(4 \mu \mathrm{m}) / \mathrm{Cr}_{2} \mathrm{~N}(1 \mu \mathrm{m})$ and an $4 \mu \mathrm{m}$ inner $\mathrm{Cr}-\mathrm{N}(\mathrm{ss})$ layer that are consistent with the $4: 1$ ratio of $\mathrm{Cr}-\mathrm{N}(\mathrm{ss})$ to $\mathrm{Cr}_{2} \mathrm{~N}$ (Magnification=1.000X). and (b) SEM image of the thin chromium-nitride coating an $0.3 \mu \mathrm{m}$ outer $\mathrm{Cr}_{2} \mathrm{~N}$ layer and an $0.6 \mu \mathrm{m}$ inner $\mathrm{C}-\mathrm{N}$ (ss) layer that are consistent with the 2:1 ratio of $\mathrm{Cr}-\mathrm{N}(\mathrm{ss})$ to $\mathrm{Cr}_{2} \mathrm{~N}$ (Magnification=2.000X). 


\section{Nitride Layer Thickness [microns]}

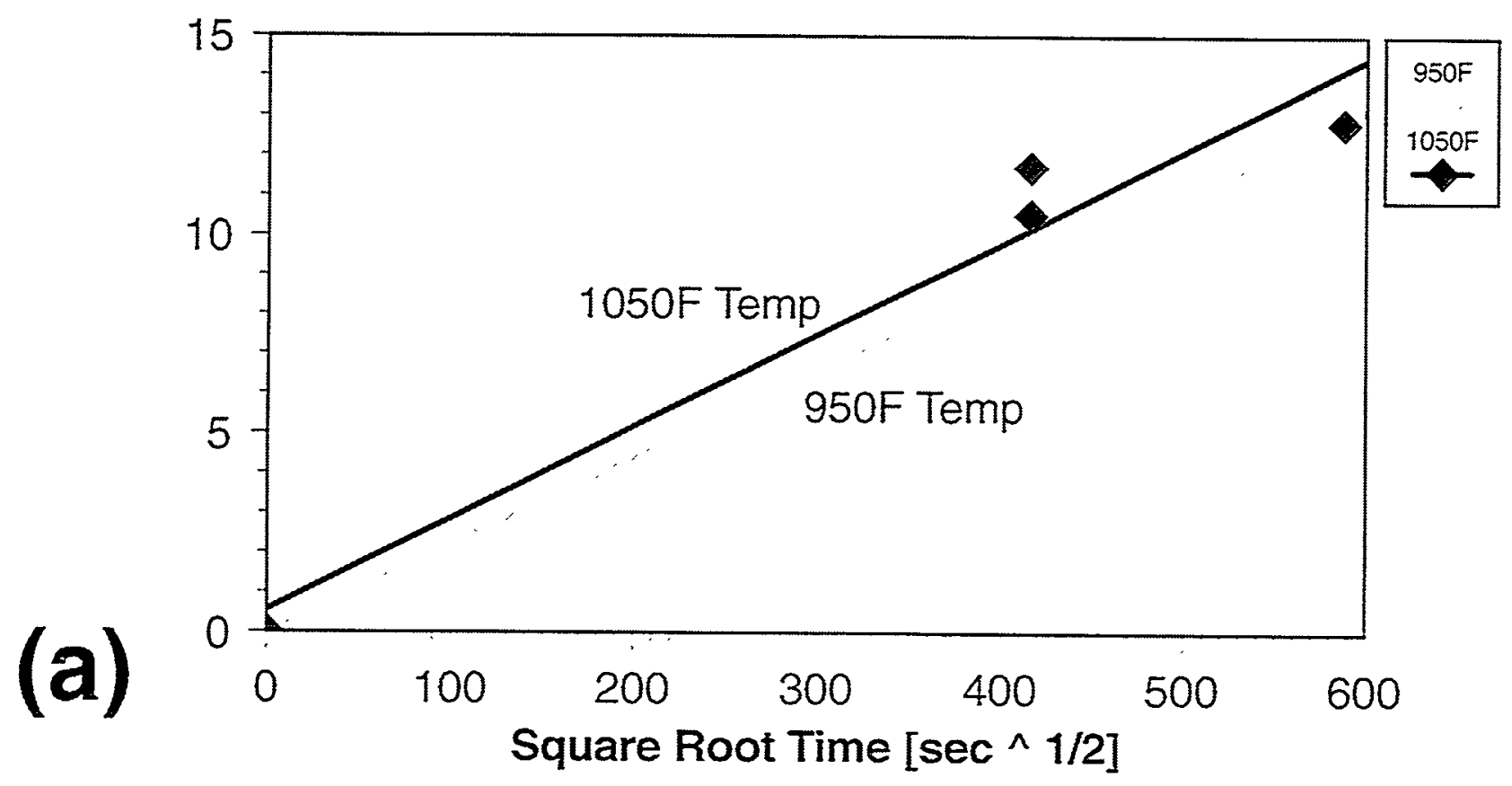

(b)

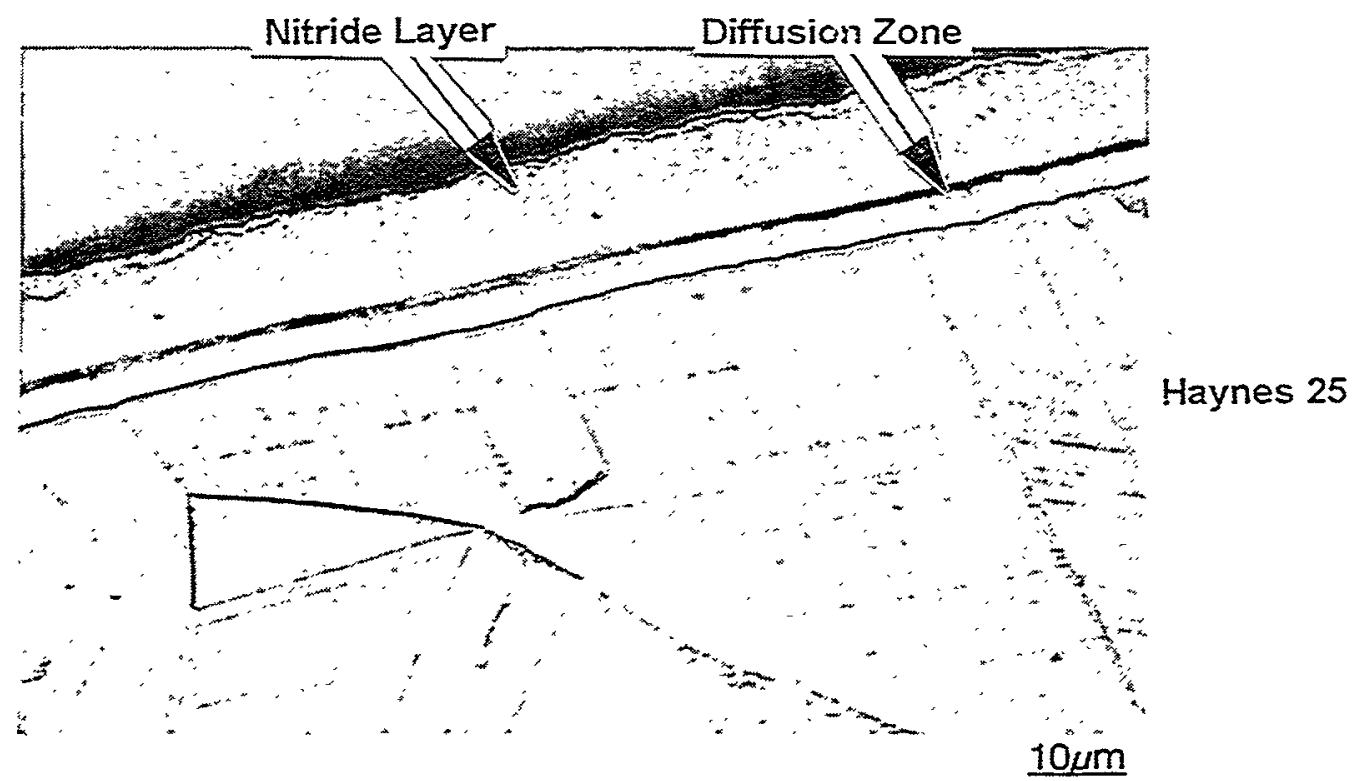

Fig. 3. Ion nitriding of Haynes 25: (a) plot of nitride layer thickness versus the square root of time for the $510^{\circ} \mathrm{C} / 48 \mathrm{~h} .566^{\circ} \mathrm{C} / 48 \mathrm{~h}$ ( $2 \mathrm{runs}$ ) and $566^{\circ} \mathrm{F} / 96 \mathrm{~h}$ ion nitriding runs with least square fit to the data giving parabolic rate constants of $\mathrm{k}_{\mathrm{p}}\left(510^{\circ} \mathrm{C}\right)=4.8 \times 10^{\circ: 2} \mathrm{~cm}^{2} / \mathrm{s}$ and $\mathrm{k}_{3}\left(556^{\circ} \mathrm{C}\right)=5.3 \times 10^{-12} \mathrm{~cm}^{2} / \mathrm{s}$, and (b) metallographic section of an ion nitrided Haynes 25 ball showing an outer ion nitride layer and an inner diffusion zone (Magnification=1.000X). 


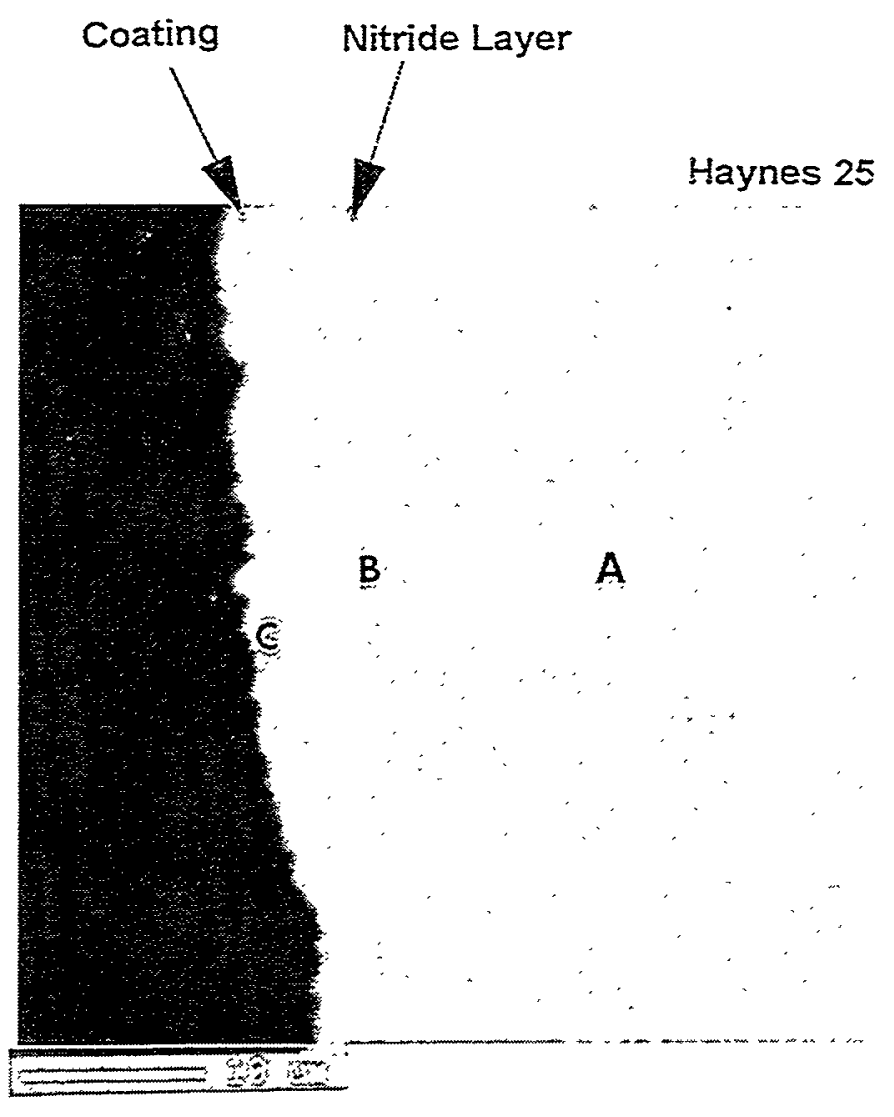

Fig. 4. SEM micrograph of the cross-section of a thin duplex coating deposited on Haynes 25 at $2.000 \mathrm{X}$ magnification. The duplex coating consists of a $1, \mu \mathrm{m}$ outer coating (with a $0.3 \mu \mathrm{m}$ outer $\mathrm{Cr}_{2} \mathrm{~N}$ laver and an $0.6 ; \mathrm{m}$ inner $\mathrm{Cr}-\mathrm{N}(\mathrm{ss})$ layer that are consistent with the $2: 1$ ratio of $\mathrm{C}_{\mathrm{T}-\mathrm{N}} \mathrm{N}(\mathrm{ss})$ to $\mathrm{C}_{7_{2}} \mathrm{~N}$ ) deposited on a nitriced layer. 